\title{
THE POSSIBILITY OF USING WAQF TO FINANCE THE MALAYSIAN FEDERAL GOVERNMENT'S PUBLIC EXPENDITURE
}

\author{
${ }^{1,2}$ Azniza Hartini bt Azrai Azaimi Ambrose, ${ }^{*}$ \\ ${ }^{1}$ Mohamed Aslam \& ${ }^{1}$ Hanira Hanafi \\ ( ${ }^{*}$ First author) \\ ${ }^{1}$ Faculty of Economics and Administration, University of Malaya \\ ${ }^{2}$ Kulliyyah of Economics and Management Sciences, \\ International Islamic University Malaysia \\ (azniza_azrai@iium.edu.my, maslam@um.edu.my, hanira_hanafi@um.edu.my) \\ DOI: https://doi.org/10.22452/jati.vol23no2.5
}

\begin{abstract}
The purpose of this paper is to examine the possibility of using waqf to finance the federal government's public expenditures in Malaysia. The arguments were based on the primary data gathered from semi-structured interviews with waqf experts. The result shows that waqf can finance the Malaysian federal government's public expenditure for three reasons; Shari'ah permissibility, there is evidence of implementation in past Muslim economies and political will from the federal government. This study is motivated by Malaysia's persistent primary deficit, Malaysia's rising debt to GDP, and the versatile nature of waqf that could address these problems. Due to the exploratory nature of this study, qualitative research was conducted through the employment of semi-structured interviews. The thematic analysis was then performed on the interview transcripts. Literary evidence was also mentioned to ensure the concurrent validity of the mentioned results. The findings of this paper may add to the existing literature on the solutions to the burgeoning government expenditure and debt. Even more so, this article motivates researchers to explore the arising issues stemming from this particular waqf implementation.
\end{abstract}

Keywords: waqf, finance, third sector, public goods, public expenditure 


\section{Introduction}

Waqf or wakaf can be defined from the economic perspective as "diverting funds (and other resources) from consumption to investing them in productive assets which provide either usufruct or revenues for future consumption by individuals or group of individuals" (Kahf, 2014, p. 201). It is an instrument of the third or voluntary sector (Faridi, 1983; Kahf, 2014; Mohd. \& Mohamed, 2016) governed by a set of Sha'riah laws. It has even been adopted to some extent by non-Muslims during the late Ottoman era (Shaham, 1991).

Aside from its regular religious role, waqf was the provider of pure and mixed public goods in Islamic history. In the context of the modern economy, this role is borne by the federal government by incurring expenditure which indirectly resulted in the burgeoning expenditure and rising debt. Malaysia, the country in this case study, is facing persistent primary deficit (see Figure 1) and rising federal government debt to the gross domestic product (GDP) (see Figure 2). Due to these circumstances, the Malaysian federal government had opted to reduce its expenditure and increase tax by introducing the goods and services tax (GST). According to Konzelmann (2014), the combination of reducing expenditure and increasing tax could negatively affect the welfare of the country.

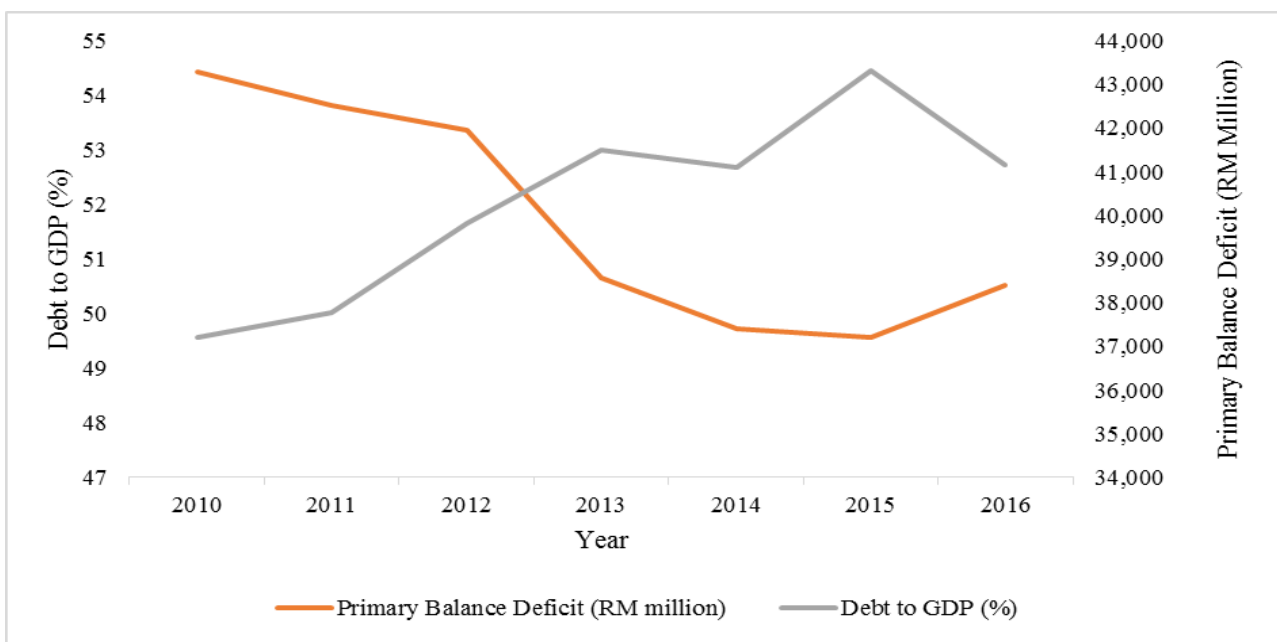

Figure 1: The Malaysian Federal Government Primary Balance Deficit and Debt to GDP Ratio

Source: Bank Negara Malaysia (2017)

Public expenditures consist of components that take into account the welfare of the general public. This is similar to the function of waqf as a third 
sector instrument. Should waqf cater to public expenditures, the public's welfare will indirectly be taken care of, expenditures may not be reduced, and increase in tax may be unnecessary. Using waqf to finance public expenditure will have other implications. Firstly, the Malaysian government will borrow lesser which in itself, have two other effects. One, Malaysia's debt to the GDP ratio can be steadily reduced. Two, the government can gradually avoid from being involved in the payment of riba' (interest) that is abhorred in Islam. Secondly, waqf may be presented as a possible fiscal tool aside from the typical conduct of the fiscal and monetary policy. In other words, the third sector could to some extent be integrated into the public sector.

Hence, this paper aims to analyse the possibility of using waqf to finance the Malaysian federal government's public expenditures to address those problems mentioned earlier. Waqf is a versatile third sector instrument and is developing rapidly in Malaysia. This is evidenced by the allocation of the federal government's budget for waqf development, progressive waqf law amendments, as well as numerous waqf for mixed public goods. Mixed public goods are constituents of the government expenditures which are directly related to the topic of this paper.

The arguments are presented in five main sections including the introduction section. The second section contains a literature survey regarding the topic of this article. The third section explains the adopted research methodology while the fourth section highlights the findings. Lastly, the fifth section concludes this paper.

\section{Literature Review}

As stated in Mohsin (2013), Al-Sarakhsi and Ahmad (1906) delineated three principles or key restrictions of waqf namely perpetuity, inalienability, and irrevocability. Perpetuity dictates that the corpus of waqf must be nonperishable, stay permanently intact, and does not cease easily. Inalienability stipulates that the asset of waqf must not be sold, inherited, or be given away as a gift. Lastly, irrevocability states that when an asset is declared as waqf, it will forever remain as such. These principles practically guarantee the continuous benefit of waqf, making it a sustainable instrument for financing the government's expenditures.

The ijtihad (exhaustive and critical thinking) among Islamic jurists provides more flexibility in implementing waqf. For instance, cash can be converted into waqf according to Imam Zufar from the Hanafi madhab (Çizakça, 1998; Mohsin, 2013) even though the value of cash may decrease due 
to inflation. This may be derived from the opinion of Ebu's Su'ud where the type of asset suited for waqf endowment is influenced by the contemporary custom of that place (Imber, 1997). Another example is the process of ibdal and istibdal. The former involves the actual selling of unproductive waqf property while the latter substitute the original waqf property with another through the act of purchasing (Department of Awqaf, Zakat, and Hajj, 2010; Siraj, 2012). A cursory look may cause one to claim these as violations of the waqf principles. In essence, ibdal and istibdal have the purpose of guaranteeing the perpetual benefit from waqf while the benefit derived from cash is not to be underestimated hence fully utilised as waqf.

Since Malaysia consists of people from different religious backgrounds, it is important to consider the application of waqf for nonMuslims. According to Razali (2015) and Mohsin (2009), both Muslims and non-Muslims can be the founder and beneficiary of waqf. Permissibility of waqf creation by non-Muslims is based on the following hadith:

Verily, Allah does not treat a believer unjustly in regard to his virtues. He would confer upon him (His blessing) in this world and would reward him in the Hereafter. Moreover, as regards a non-believer, he would be made to taste the reward (of virtue in this world) what he has done for himself so much that when it would be the Hereafter, he would find no virtue for which he should be rewarded. (Sahih Muslim, n.d.)

Meanwhile, the permissibility for non-Muslim to be waqf beneficiary is based upon the action of Shafiyah binti Huyaii, the wife of Prophet Muhammad (PBUH), who had made her Jewish relatives as beneficiaries of waqf.

Indeed, the versatile characteristics of waqf had turned it into a significant provider of public goods, mixed public goods, and other social services in Islamic history. Prophet Muhammad (PBUH) had used properties that were left by Mukhayriq as a waqf to finance defence, and Uthman bin Affan had bought a well in Madinah to provide free drinking water (Gil, 1998; Kahf, 2014). During the Umayyad Caliphate, Diwan al-Ahbas was formed by the state to avoid the misuse of waqf (Mohsin, 2009) and later on, Sultan Salahuddin al Aiyyubi introduced a new waqf policy in the Nile Valley (Frenkel, 1999). Waqf then reached its zenith in the Ottoman era where waqf had equalled one-third of the state's total revenue (Kuran, 2001). Throughout these stages in history, waqf had provided for education, road maintenance, Hajj expenses, marriage expenses, housing, hospitals, defence, businesses, and 
employment opportunities among others (Çizakça, 1998; Frenkel, 1999; Mohsin, 2009; Babacan, 2011; Kahf, 2014).

One reason for this significant role of waqf is that previous Islamic governments tended to have smaller public roles in contrast to private initiatives (Faridi, 1983; Azmi, 2002). Even though the capacity of Islamic governments became bigger, later on, the role of waqf as the provider of pure and mixed public goods did not diminish (Azmi, 2002). This may be attributed to the altruistic behaviour of humans and the motivation to attain God's pleasure which is often overlooked in modern economic theories.

Anyhow, Siddiqi (1995) and Babacan (2011) classified waqf as a state revenue instead. This might be because Islamic governments inherited waqf properties dedicated to public goods from their predecessors. These suggest that waqf is inherently intermediary between the third sector, private sector, and public sector; very akin to the European third sector framework developed by Pestoff (1992). There are numerous studies pertaining to the third sector in Europe where a compilation can be found in Evers and Laville (2004). It goes to show that altruism and the voluntary sector are relevant in modern economics too.

Due to a number of reasons, the waqf system had faced a decline in the early nineteenth century. Among these reasons were the lack of focus on capital pooling, complicated bureaucratic procedures, corruption, and the inability of waqf to assimilate into an industrialised economy (Mandaville, 1979; Çizakça, 1998, Kuran, 2001; Çizakça, n.d.). Çizakça (1998) assumed more income could be gained and loss could be avoided if cash waqf were also invested instead of merely given out for consumption. Meanwhile, the complicated bureaucratic procedures had deterred further establishment of waqf. Corruption had also occurred both at the government and public level. An example of the public level is the case of public waqf at Damascus and Jerusalem between the 16th and 20th century. Baer (1997) argued that the founders would usually appoint a family member to manage the waqf. As a manager, that family member received a large portion of the waqf income which leaves the beneficiaries with less.

On top of that, the administrators of this public waqf had a significant influence on societies and politics; akin to a tycoon with ill intentions funding an election campaign. Hence, Baer (1997) believed that these administrators only wanted to gain control of public goods. Meanwhile, an example of corruption at the government level was given by Çizakça (n.d.) whereby waqf was forced to be invested in economic ventures that had a high probability of loss. 
Kuran (2001) asserted that "the historical pattern might have been different had the regulations governing the waqf evolved into an enterprise enjoying corporate status" (p. 843). This quoted phrase by Kuran (2001) elucidates the fact that the demise of waqf was not due to its inherent nature but the manner it was regulated. Hence, using waqf to finance modern federal government public expenditures is not necessarily capricious.

Focusing on the modern Malaysian economy, the role of waqf as the provider of pure and mixed public goods has reduced significantly due to the obvious reason that these goods are mainly provided for by government expenditures. Nonetheless, waqf is acquiring more economic role since the culmination of the Ninth Malaysia Plan. As stated in point 70 of the former Prime Minister's speech, Tun Abdullah Ahmad Badawi during its launch:

Meanwhile, we will continue to develop sources of capital for Bumiputera, for example, land and wakaf assets currently under the state of Islamic religious authorities. The state Islamic religious authorities need to shoulder the responsibility of fardu kifayah, play an active role to develop the economy of Muslims and assist in the development of human capital. (Abdullah, 2006, p. 36)

Two implications arose from this. The first implication is the allocation of the budget by the federal government to develop waqf. The funding was disbursed to the State Islamic Religious Councils (SIRCs) by instituting Yayasan Waqaf Malaysia (YWM) as the federal government trust body (Yayasan Waqaf Malaysia, n.d.; Sanep \& Nur, 2011) while retaining the SIRCs as the sole trustee of waqf in Malaysia (Siti, 2011). Another government organisation that was instituted as part of the waqf development plan is the Department of Awqaf, Zakat, and Hajj (JAWHAR). Among the department's initiative is the publication of various waqf manuals to streamline the management and laws of waqf in Malaysia (Sharifah, 2016).

The second implication is waqf law amendments in certain states. For example, Section 23(1) of the Wakaf (State of Selangor) Enactment 2015 states that (n.d.):

The Corporation may accept-

(a) shares, bonds, sukuk or other instruments for valuable guarantee; and

(b) benefits from the units of share, bonds, sukuk or other instruments for the said valuable guarantee, given by way of wakaf 
by any person, society or institution provided that the business or investment carried out is consistent with Hukum Syarak.

From this stipulation, more assets can be converted into waqf thus expanding the opportunity for more people to contribute. A recent example would be the development of Larkin Sentral Property Berhad through the issuance of shares in the Malaysian capital market (Larkin Sentral Property Berhad, 2017). The purpose of this waqf is to finance the upgrade of Terminal Building of Transport and Public Market at Larkin, Johor Bahru. It is important to note also that cash waqf has been deemed permissible in Malaysia based on the fatwa by the National Fatwa Council Islamic Affairs of Malaysia that had convened on 10 to 12 April 2007.

Another example of waqf law amendment is the appointment of nazir khas (private manager) of waqf. For instance, Section 33(1)(a), 33(1)(b), and 33(1)(c) from Wakaf (State of Negeri Sembilan) Enactment 2005 states that (2017):

(1) The Majlis, on the advice of the Advisory Panel, may-

(a) appoint any person whom the Majlis reasonably considers competent and qualified to manage and develop any mawquf, including to manage the investments of the mawquf; (b) appoint any person whom the Majlis reasonably considers competent and qualified to manage the benefits, interests or profits of any mawquf in the interest of its mawquf-alaih; and (c) appoint any agent whom the Majlis reasonably considers competent and qualified, whether a solicitor, banker, licensed financial advisor or any other person, to execute any transaction required in managing the affairs of the wakaf.

Allowing for the nazir khas to manage waqf has two other ramifications. The first ramification is that other organisations may manage their waqf fund thus presenting opportunities for them to establish theirown waqf funds. One example is the Al-Abrar Waqf Fund founded by the Islamic Science University of Malaysia (USIM). The second ramification is a financial institution, and SIRC may jointly collaborate. This is highly beneficial because financial institutions have more knowledge and experience in accumulating capital hence further ensuring the sustainability of waqf. One excellent example is the cash waqf management between Bank Muamalat Malaysia Berhad and 
Perbadanan Wakaf Selangor (PWS), a corporation under the SIRC of Selangor (Wakaf Selangor Muamalat, n.d.). The waqf laws and management in Malaysia are steadily evolving which may give room for the application of waqf financing federal government public expenditures.

The development in Malaysian waqf law and management had caused a proliferation of waqf for mixed public goods and other social services. These include providing shop lots, orphanages, hotels, student hostels, low cost housing units, Islamic school complexes, business space, complex for new Islamic converts, haemodialysis centre, women shelter, university waqf funds, boats for fishermen, and residential colleges (Perbadanan Wakaf Negeri Sembilan, n.d.; Center for Awqaf and Zakat, n.d.; Perbadanan Wakaf Selangor, 2011-2014; Wakaf Selangor Muamalat; n.d.; Waqaf Perak Ar-Ridzuan, n.d.; eWakaf Johor, n.d.; Department of Awqaf, Zakat and Hajj, n.d.). Zurina, Zamir, and Mustafa (2016) had listed nine institutions of higher learning that employ the use of waqf fund while Ainul, Arieff, and Azman (2014) had analysed the potential of waqf for the Malaysian health sector. These are the components of federal government's development expenditure which can be categorised into housing, health, education, trade and industry, agriculture and rural developments, as well as social and community services (Bank Negara Malaysia, 2017). It indicates that waqf can finance these expenditures which in reality have a direct benefit to the Malaysian public. Of course, more evidence is needed to justify this assertion.

To the knowledge of the researchers, there is only one known similar implementation of waqf that this article is examining. However, its progress is unknown. During the rule of Hosni Mubarak (1981-2011) in Egypt, the Ministry of Awqaf had introduced a policy called majhud dhati or juhud dhatiyya which means "self-effort". The policy encourages the mosque to become welfare providers and provide services like teaching (Pioppi, 2004). The government is asking the Egyptian society to "autonomously find the economic resources to finance those services and support activities that used to be a state duty" (Pioppi, 2004, p. 5). In this case, the Egyptian government is employing waqf as a pure third sector instrument and not as a hybrid instrument (public sector, the private sector, and third sector) that this section had inferred earlier on.

\section{Research Methodology}

To examine the possible role of waqf to finance the Malaysian federal government's public expenditures, this study gathered primary data through 
semi-structured interviews involving eight informants selected through theoretical sampling. They consisted of five academicians, two government bodies, and one expert of waqf from the industry. The interviews were mostly conducted face to face while one was conducted through email. With permissions from the interviewees, the interviews were recorded and transcribed. Thematic analysis was then manually conducted on the interview transcripts. The transcripts were read to acquire a general meaning. Using the "Table" function in Microsoft Word, the themes and condensed answers from the interviewees were organised. Since most of them chose to remain anonymous, the interviewees were named in Roman numerals. To guarantee that the findings are concurrently valid, the literature that supports the qualitative findings was also cited. It should be noted that the interviewees have backgrounds in Malaysian waqf management, the history of waqf, economics, and finance which add to the findings' validity.

\section{The Viability of Waqf Financing Federal Government Public Expenditure}

The majority of the interviewees' stated that waqf could finance federal government public expenditure. This claim was supported by three major themes that had emerged from the interview transcripts which were Shari'ah permissibility, previous Islamic economies' use of waqf, and political will.

\section{Allowance in the Shari'ah}

The interviewees that are in support of this idea unanimously agree that there is no Shari'ah contradiction in this implementation of waqf. In the words of Interviewee I during an interview on 5 April 2016, "I cannot see any Shari'ah issue as long as you observe all the Shari'ah requirements and the laws that would be fine". This statement firmly supported the idea of waqf financing the federal government's public expenditures in Malaysia.

The Shari'ah requirements are the principles of waqf which was outlined by Al-Sarakhsi and Ahmad (1906). To reiterate, the principles are irrevocability, perpetuity, and inalienability. The modus operandi for waqf financing public expenditure is legitimate so long as these aspects were accounted for. Besides that, the claim by Ebu's Su'ud that waqf follows the contemporary custom (Imber, 1997) may provide further justification for the implementation of waqf in this context. In modern economies, it is the norm for the federal government to provide public goods, mixed public goods, and other social services. Thus by extension, waqf financing public expenditures should be deemed permissible. 
Meanwhile, Interviewee II during a personal interview on 10 August 2016 stressed that caution must be exercised:

It is the government's function to take care of the public. So if we put waqf in the position where we move the government's burden to society, I do not agree. However, if waqf assumes a complementary role, then it can be [instituted]... It is not that waqf must take care of society and government should divert its function.

To rephrase, the contribution of waqf for public goods, mixed public goods, and social services should not be made mandatory. Instead, waqf should only be made supplementary. It must be duly noted that waqf is a third sector instrument that should be voluntarily endowed which is different from the tax that is compulsory. Besides, a small government role in contrast to a greater private role like that of past Muslim economies is not practical for the current Malaysian economy. In the age of rapid industrialisation, information technology, globalisation, trade, and commerce, the government's role has become vast in comparison to the governments in history. Subsequently, it can be argued that the majhud dhati policy adopted by Egypt is not suitable for Malaysia.

In terms of the law, Interviewee I was referring to the Malaysian waqf laws. Specifically, the implementation of waqf for financing the federal government's public expenditure must recognise the difference of the state waqf laws. Hence, a modus operandi for the application of waqf in question must accommodate these laws. Note that there already exists progressive waqf enactments such as the stipulations that permit the appointment of nazir khas and the inclusion of various asset classes for waqf endowments. Perhaps, other stipulations should be included to initiate this particular implementation of waqf. As a matter of fact, Sharifah (2016) had conducted a study promoting the standardisation of waqf laws in Malaysia. If this comes into fruition, providing public goods, mixed public goods, and social services through waqf will be easily facilitated. This is due to the benefits of a uniform law namely positive public perception, heightened transparency, cheaper transaction cost, and reduced bureaucracy (Sharifah, 2016). Nonetheless, the development of this modus operandi will not be discussed further because it diverges from the intention of this article. 


\section{Evidence of Application in Past Islamic Economies}

The second justification for the idea of waqf financing federal government public expenditures is its successful implementation in previous Muslim economies. This was recognised by Interviewee III during an interview on 24 January 2016, Interviewee IV during an interview on 7 January 2016, Interviewee $\mathrm{V}$ during an interview on 31 March 2016, Interviewee VI during an interview on 7 June 2016, Interviewee VII during an interview on 10 March 2016, and Interviewee VIII during an interview on 18 January 2017. As elucidated by Interviewee $\mathrm{V}$ :

You see when we talk about waqf and go back to the Ottoman experience, they use waqf and they also use cash waqf even to finance the economics, precisely to finance the army and military force. It has been used, yes and it was successfully done, yes, and it can happen again because the concept is the same.

As was discussed in the literature review section, the pure and mixed public goods, as well as other social services, have previously been successfully catered for by waqf (Çizakça, 1998; Gil, 1998; Mohsin, 2009; Kahf, 2014). It had even become an instrument of public policy in previous Islamic states and could be a hybrid instrument of the public and voluntary sector. Hence, one would assume that this application of waqf is anachronistic. However, the third sector, in general, is not. As evident in Pestoff (1992) and Evers and Laville (2004), the third sector concept in the public sector is gaining traction in modern European economies. These had motivated Mohd. Moreover, Mohamed (2016) to situate waqf, which is a third sector instrument, in modern socio-economic models. Further considering the multi-religious setting of Malaysia, the application of waqf will not discriminate non-Muslims as was expounded by Mohsin (2009) and Razali (2015). To include waqf in the current economic setting will fulfil the former Prime Minister, Tun Abdullah Ahmad Badawi's legacy. Thus, it is appropriate and relevant for Malaysia to apply waqf to finance the federal government's public expenditure.

Section 2 had already identified the components of the federal government's expenditures that are suitable for waqf. Interviewee IV had further included the component of subsidy:

Now let's go to the point of subsidy. The government is subsidising for many things. Subsidising for education, housing. Now all of those 
subsidies, if you give it to the waqf, I am sure a lot will be reduced. Moreover, the contribution will be immense.

Further detailed research can be done to precisely identify the components of the federal government's expenditure that can be financed by waqf.

\section{Political Will of the Federal Government}

The third and most stanch support for the implementation of waqf in this context is the evidence of a political will. Interviewee VI during an interview on 7 June 2016 and Interviewee VII during an interview on 10 March 2016 confirmed this. The interviewees respectively claimed that:

Even now, the [federal] government is looking forward to corporate waqf. Of recent, the Prime Minister himself did mention that corporate waqf should be developed further. Meaning eventually, it [waqf] will assist the federal government. It is just in Malaysia; waqf is under the jurisdiction of the state. So development [of waqf] only involves the states. As for the federal government, waqf collection is still at the initial stage.

Our grand view is, waqf will in the future replace many sectors such as health, education. This leaves the federal government to focus on others that are more important... Therefore [waqf] can lessen the government's burden.

To a certain extent, employing waqf as a supplementary fiscal tool had also been indicated by Sanep and Nur (2011) when the federal government had funded the development of waqf. Following this, six waqf manuals were published by JAWHAR in order to promote the best practices in Malaysian waqf management (Sharifah, 2016). This effort had prompted a few SIRCs to revise their laws on waqf in order to be more progressive. For instance, the upgrading of Terminal Building of Transport and Public Market at Larkin, retaining the SIRC of Johor as the nazir am (general manager) while appointing a nazir khas for that waqf. These initiatives had subsequently caused an increase in waqf for public goods, mixed public goods, and social services as was explained in Section 2.

The fact of the matter is, although SIRCs are the sole trustees of waqf in Malaysia, various methods were figured out so that the federal government can jointly develop waqf with SIRCs. This happened after the decision of the former Prime Minister, the symbol of political will back then, to mobilise waqf. 
Since there is evidence right now of political will for the implementation of waqf in question, other methods can surely be found to realise waqf financing of the federal government's public expenditures.

Nonetheless, there is one interviewee who opposed the idea of waqf financing public expenditures. Interviewee III claimed:

Now, why should a person in Malaysia make waqf to help the government's budget? Because, it is possible that sometimes the government may use it in a wrong way, for extravagant expenses. I would rather, anybody I think, would be rational to make waqf for education, to make waqf for the hospital, to make waqf for improving the roles in the country, or in any area of the country, that is specifically for something that is good.

The interviewer disagreed because of the potential mismanagement by the government. To put it simply, Interviewee III acknowledged that waqf could finance public expenditures, but due to the possibility of government mismanagement, Interviewer III disproved of the idea.

Interviewee III elucidated the acknowledgement upon reflecting on the governance of Umar ibn Khattab:

We had an example that there was in fact where waqf hadclearly helped public finance that was considered the revenue of the budget. That was what Umar ibn Khattab did in creating the waqf of the lands of the newly conquered lands. Moreover, he said this is the waqf for the ummah or to support its budget. From it yes, the budget has continuously and classically financed by the waqf.

Anyhow, the stand of Interviewee III regarding government corruption is founded in the literature. The issue of government corruption had indeed been recorded in history and had become one of the factors that contributed to the downfall of waqf (Çizakça, n.d.). Still, corruption is an isolated problem that can manifest in both public and private sector institutions as demonstrated in Section 2. As such, this paper recognises the issue of mismanagement, but it would be a prejudice to associate mismanagement with the federal government per se. Take the Tabung Harapan Malaysia as an example. It had been launched to collect public contributions to pay off the government's debt which had since received positive feedback from many Malaysians. In other words, there is indeed a possibility that 
Malaysians will endow waqf for mixed public goods and social services; given that they have confidence in the administration of waqf and the government.

Hence, it would be fair if proactive steps are instituted to combat corruption in all forms of the organisation. For instance, the Malaysian AntiCorruption Commission could continue to carry out corruption prevention measures at the government's level while accounting audit can be carried out on the private level. This is only a general recommendation which is out of the scope of this article.

\section{Conclusion}

This article had provided reasons for the possible implementation of waqf to finance the Malaysian federal government's public expenditure. The reasons include Shari'ah permissibility, similar implementation in Islamic history, and political will. It presents another alternative for the Malaysian federal government to address the issue of the burgeoning expenditure and rising debt while considering public welfare. However, its role must be recognised as only supplementary which is not meant to substitute other sources of government revenue. The findings of this paper had also pointed out several issues that can be covered in future research.

\section{Implications}

Burgeoning expenditure can be addressed by identifying the expenditure components that is suitable for waqf to finance. It is suggested that waqf finances the Malaysian expenditure components that are directly concerned with the welfare of citizens such as the development expenditure component and subsidies. This will require collaboration between YWM, SIRCs and financial institutions, reforms in waqf management, reforms in the Malaysian waqf laws, and creating awareness among the Malaysian citizens regarding the role of waqf in providing pure and mixed public goods. When this is established, government debt may then be inadvertently reduced. As development expenditure component and subsidies are catered for by waqf, government borrowings can gradually diminish, and debt to GDP may fall. 


\section{References}

Abdullah, A. B. (2006). Speech by the Prime Minister YAB Dato' Seri Abdullah Ahmad Badawi at the tabling of the motion on the Ninth Malaysia Plan, 20062010 Dewan Rakyat, 31 March 2006. Economic Planning Unit's website. Retrieved from http://www.epu.gov.my/sites/default/files/Message\%20from\%20YAB\%2 0Prime\%20Minister.pdf

Ainul, K. K., Arieff, S. R., \& Azman, A. (2014). Konsep wakaf kesihatan dan perkembangannya di Malaysia. In Proceedings of the Asean Islamic Endowment Seminar 2014 [IQLIMI 2014] (pp. 463-483). Nilai: Universiti Sains Islam Malaysia.

Al-Sarakhsi, M., \& Ahmad, K. (1906). Kitab Al-Mabsut. Cairo: Maktba'at AlSa'adah.

Azmi, S. (2002). Islamic Economics: Public finance in early Islamic thought. New Delhi: Goodword Books.

Babacan, M. (2011). Economics of philanthropic institutions, regulation and governance in Turkey. Journal of Economic and Social Research, 13(2), 61-89.

Baer, G. (1997). The waqf as a prop for the social system (sixteenth-twentieth centuries). Islamic Law and Society, 4(3), 264-297.

Bank Negara Malaysia. (2017). Monthly statistical bulletin. Bank Negara Malaysia's website. Retrieved from http://www.bnm.gov.my/index.php?ch=en_publication\&pg=en_msb\&la ng=en\&mnth=9\&yr=2017

Center for Awqaf and Zakat. (n.d.). Utama. Center for Awqaf and Zakat's website. Retrieved from http://pppw.usim.edu.my/ms

Çizakça, M. (1998). Awqaf in history and its implications for modern Islamic economies. Islamic Economic Studies, 6(1), 43-70.

Çizakça, M. (n.d.). Towards a comparative economic history of the waqf system. INCEIF Forums. Retrieved from http://inceifstudents.lefora.com/attach/view/ma/cf2a79b0463e3c0201f0d21d4d302af3f f526c96.pdf

Department of Awqaf, Zakat and Hajj. (2010). Manual Pengurusan Wakaf Tunai. Putrajaya: Department of Awqaf, Zakat and Hajj.

Department of Awqaf, Zakat and Hajj. (n.d.). Awqaf section. Department of Awqaf, Zakat and Hajj's website. Retrieved from http://www.jawhar.gov.my/en/bahagian-jawhar/bahagian-wakaf/ 
Evers, A., \& Laville, J.-L. (2004). Defining the third sector in Europe. In A. Evers \& J.-L. Laville (Eds.), The Third Sector in Europe (pp. 11- 42). Cheltenham, Northampton: Edward Elgar.

eWakaf Johor. (n.d.). Projek wakaf pembelian mesin hemodialisis. eWakaf Johor's website. Retrieved from http://www.ewakafjohor.gov.my/v2/index.php?option=com_content\&view=article\&id $=80$

Faridi, F. R. (1983). A theory of fiscal policy in an Islamic state. In Z. Ahmed, Munawar Iqbal, \& M. Fahim Khan, Fiscal policy and resource allocation in Islam (pp. 27-58). Islamabad and Leicester: Institute of Policy Studies and International Centre for Research in Islamic Economics.

Frenkel, Y. (1999). Political and social aspects of Islamic religious endowments ("awqaf"): Saladin in Cairo (1169-73) and Jerusalem (1187-93). Bulletin of the School of Oriental and African Studies, University of London, 62(1), 1-20.

Gil, M. (1998). The earliest waqf foundations. Journal of Near Eastern Studies, 57(2), 125-140.

Imber, C. (1997). Ebu's-Su'ud: The Islamic Legal Tradition (1st ed.). California: Stanford University Press.

Kahf, M. (2014). Islamic Economics: The Charitable Sector. Ad Dawhah, Qatar: Monzer Kahf.

Konzelmann, S. (2014). The political economics of austerity. Cambridge Journal of Economics, 38(4), 701-741.

Kuran, T. (2001). The provision of public goods under Islamic law: Origins, impact, and limitations of the waqf system. Law \& Society Review, 35(4), 841-898.

Larkin Sentral Property Berhad. (2017). Waqaf Saham Larkin Sentral's website. Retrieved from http://www.waqafsahamlarkin.com/prospectus.pdf

Mandaville, J. E. (1979). The cash waqf controversy in the Ottoman empire. International Journal of Middle East Studies, 10(3), 289-308.

Mohd., N. M., \& Mohamed, A. M. (2016). Third sector socio-economic models: How waqf fits in? Institutions and Economies, 8(2), 75-93.

Mohsin, M. I. (2009). Cash Waqf: A New Financial Product (1st ed.). Kuala Lumpur: Pearson Malaysia Sdn. Bhd.

Mohsin, M. I. (2013). Financing through cash waqf: A revitalisation to finance different needs. International Journal of Islamic and Middle Eastern Finance Management, 6(4), 304 - 321.

Perbadanan Wakaf Negeri Sembilan. (n.d.). Home. Perbadanan Wakaf Negeri Sembilan's website. $\quad$ Retrieved from http://www.wakafnegerisembilan.com/ 
Perbadanan Wakaf Selangor. (2011-2014). Laporan pengurusan wakaf di Selangor pada tahun 2011 - 2014. Shah Alam: Perbadanan Wakaf Selangor.

Pestoff, V. A. (1992). Third sector and co-operative services - An alternative to privatization. Journal of Consumer Policy, 15, 21- 45.

Pioppi, D. (2004). From religious charity to the welfare state and back: The case of Islamic endowments (waqfs) revival in Egypt. European University Institute's website. Retrieved from http://cadmus.eui.eu/bitstream/handle/1814/2776/04_34.pdf?sequence=1 \&isAllowed $=\mathrm{y}$

Razali, O. (2015). Institusi Wakaf Sejarah dan Amalan Masa Kini. Kuala Lumpur: Dewan Bahasa dan Pustaka.

Sahih Muslim. (n.d.). Book of Characteristics of the Day of Judgment, Paradise, and Hell, Hadith 6739, US-MSA Web (English) reference. Sunnah.com. Retrieved from https://sunnah.com/muslim/52

Sanep, A., \& Nur, D. M. (2011). Wakaf dalam agenda pembangunan ekonomi negara di Malaysia. Jurnal Pengurusan JAWHAR, 63-82.

Shaham, R. (1991). Christian and Jewish "waqf" in Palestine during the late Ottoman period. Bulletin of the School of Oriental and African Studies, 54(3), 460-472.

Sharifah, Z. S. (2016). Kerangka undang-undang pengurusan Wakaf di Malaysia: Ke arah keseragaman undang-undang [Legal framework for waqf management in Malaysia: Towards uniformity of laws]. Kanun, 28(1), 101-126.

Siddiqi, M. N. (1995). An overview of public borrowing in early Islamic history. Journal of Islamic Economic Studies, 2(2), 61-78.

Siraj, S. (2012). An empirical investigation into the accounting, accountability and effectiveness of waqf management in the state Islamic religious councils (SIRCs) in Malaysia. Online Research@Cardiff. Retrieved from https:/orca.cf.ac.uk/46875/8/2013\%20Siraj\%20Siti.pdf

Siti, M. M. (2011). Law of waqf in Malaysia: recent developments. In M. Kahf, \& M. M. Siti, Essential readings in contemporary waqf issues (pp. 77-106). Kuala Lumpur: CERT Publications Sdn. Bhd.

Wakaf (Negeri Sembilan) Enactment 2005. (2017). In S. K. Rashid (Ed.), Waqf laws and management (pp. 447-489). Gombak: IIUM Press.

Wakaf (State of Selangor) Enactment 2015. (n.d.). E-syariah official portal. Retrieved from http://www2.esyariah.gov.my/esyariah/mal/portalv1/enakmen2011/Eng_ enactment_Ori_lib.nsf/f831ccddd195843f48256fc600141e84/b54547a4f9c5 b07f48257f7100183ca3?OpenDocument 
Wakaf Selangor Muamalat. (n.d.). Pengenalan. Wakaf Selangor Muamalat's website. $\quad$ Retrieved from http://www.muamalat.com.my/wakafselangor/Pengenalan.html

Waqaf Perak Ar-Ridzuan. (n.d.). Projek Wakaf. Waqaf Perak Ar-Ridzuan's website. Retrieved from http://wakafperak.maiamp.gov.my/v1/index.php/projek-wpar

Yayasan Waqaf Malaysia. (n.d). https://www.ywm.gov.my/Zurina, S., Zamir, I., \& Mustafa, T. (2016). Governance regulatory framework for waqf in selected countries. In The Muktamar Waqf IQLIMI III 2016 (IQLIMI 2016). Songkla: Pusat Pembangunan Pembiyaan Wakaf (PPPW), Universiti Sains Islam Malaysia. 